\title{
Survey of Intravitreal Injection Techniques Among Retina Specialists in Mexico
}

This article was published in the following Dove Press journal: Clinical Ophthalmology

\section{Andree Henaine-Berra (ID) Vanesa Flores-Peredo ${ }^{2}$ Gabriela Lopezcarasa- Hernandez $\mathbb{D}^{3}$ \\ Maria Ana Martinez- Castellanos ${ }^{4}$ Ximena Mira-Lorenzo ${ }^{5}$ Adriana Solis-Vivanco ${ }^{6}$ Gerardo Garcia-Aguirre $\mathbb{1 D}^{7}$ \\ On behalf of Mexican Retina Association}

'Hospital San Angel Inn Universidad, Mexico City, Mexico; ${ }^{2}$ Retina Department, Hospital Regional "Lic. Adolfo Lopez Mateos" ISSSTE, Mexico City, Mexico; ${ }^{3}$ Hospital Angeles Lomas, Mexico City, Mexico; ${ }^{4}$ Retina

Department, Asociacion Para Evitar La Ceguera En Mexico, Mexico City, Mexico; ${ }^{5}$ Centro Oftalmologico Arcos, Queretaro, Mexico; ${ }^{6}$ Retina Department, Instituto Nacional De Rehabilitacion, Mexico City, Mexico; ${ }^{7}$ School of Medicine and Health Sciences, Tecnologico De Monterrey, Mexico City, Mexico
Correspondence: Andree Henaine-Berra Hospital San Angel Inn Universidad, Av. Rio Churubusco \#60I Suite 928, Xoco, Benito Juarez, Mexico City 03330, Mexico Tel +5255 6818-0116

Email andreehenaine@gmail.com
Purpose: To report technique preferences for intravitreal injections among retina specialists in Mexico.

Methods: Cross-sectional survey. Ophthalmologists with a two-year retina training, active members of the Mexican Retina Association, were contacted through email to answer a survey consisting of 37 items regarding their IVI application technique.

Results: A total of 133 retina specialists participated, with a response rate of $78 \%$. Fortyfive percent applied the intravitreal injections in an operating room designated for the procedure. Sixty-three percent reported never injecting both eyes on the same day. Ninetysix percent wore a face mask during the procedure and 91\% wore gloves. Eighty-two percent used a lid speculum. Tetracaine drops were the anesthetic method employed by $97 \%$ of participants. All participants utilized povidone-iodine for antisepsis. Eighty percent measured the puncture site with a caliper. Superotemporal quadrant was the one chosen to place the injection by $63 \%$ of participants. Fifty-nine percent indicated post-injection antibiotic drops for several days. Post-injection counting fingers visual acuity was verified by $53 \%$ of the participants. Fifty-six percent of the participants placed an eye-patch after the procedure.

Conclusion: There are different practices regarding the application of intravitreal injections among retina specialists in Mexico. Performing this type of survey periodically could show changes in preferences, as new evidence is incorporated into clinical practice.

Keywords: intravitreal injections, retinal diseases, anti-VEGF agents, topical antibiotics

\section{Introduction}

Currently, intravitreal injections (IVI) are accepted as the standard form of drug administration for a large number of retinal diseases. Despite the frequency with which they are applied and the numerous guidelines that have been published in this regard, ${ }^{1-3}$ issues such as drug preparation, injection technique, indications, followup and office vs operating room setting may vary according to surgeon preference and/or country. These practices are always aimed at preventing endophthalmitis and other complications such as retinal detachment, cataract formation and increased intraocular pressure, ${ }^{4,5}$ as well as reducing patient discomfort during the procedure.

Previous studies have reported the preferences for IVI application among retina specialists from countries like the USA, Canada, Israel, India and Brazil. ${ }^{6-11}$ To the best of our knowledge, there are no reports about these preferences in Mexico.

The aim of this study was to report the variety of practices regarding IVI application technique and pre/post-injection procedures performed by retina specialists in Mexico, members of the Mexican Retina Association, who underwent a formal two-year retina subspecialty training. 


\section{Materials and Methods}

All active members of the Mexican Retina Association $(\mathrm{n}=170)$ were invited to participate in an anonymous survey sent by e-mail on March 2nd, 2020. The questionnaire was based on previously published surveys ${ }^{6-11}$ plus other items that were considered relevant to our practice. It consisted of 37 questions written by the authors, regarding the practices before, during and after the application of IVI and was distributed using Google Forms (Google Inc. Mountain View, CA, USA). Those who did not answer the first email received a second email during May 2020 and some of them were reached through phone call. The final results were gathered on June 3rd, 2020 for analysis. This study adhered to the tenets of the Declaration of Helsinki, and the ethic committee approval was unnecessary as the anonymous questionnaire was conducted via emails.

\section{Results}

A total of 133 (78\%) out of 170 retina specialists participated in the survey. Regarding the time elapsed since they completed their specialty training, 19.5\% (26/133) had finished it in a period between 1 and 5 years, 22.6\% (30/ 133) between 6 and 10 years, 20.3\% (27/133) between 11 and 15 years, $16.5 \%(22 / 133)$ between 16 and 20 years and $21.1 \%(28 / 133)$ more than 20 years ago. Forty-four percent (59/133) had an established medical practice in Mexico City and its metropolitan area and the remaining $55.6 \%(74 / 133)$ in the rest of the country.

About the weekly physician volume of IVI, 45.1\% (60/ 133) referred to apply between 5 and 10 injections, $36.1 \%$ (48/133) less than 5 injections, $12.8 \%$ (17/133) between 10 and 20 and $6 \%(8 / 133)$ more than 20 injections. Among anti-VEGF (vascular endothelial growth factor) agents, Ziv-Aflibercept (Zaltrapziv, Sanofi-Aventis) was applied by $40.6 \%(54 / 133)$, being the most frequently used, followed by Aflibercept (Wetlia, Bayer) used by 35.3\% (47/ 133), then Ranibizumab (Lucentis, Novartis) used by 13.5\% (18/133) and Bevacizumab (Avastin, Roche) applied by $10.5 \%(14 / 133)$.

More than half of the participants (58.6\% [78/133]) requested the patient to sign an informed consent form for each injection, while $31.6 \%(42 / 133)$ asked it only for the first injection and $9.8 \%(13 / 133)$ did not request it at all.

Regarding the setting where the IVI were applied, $45.1 \%(60 / 133)$ mentioned performing them in a room specially dedicated for the procedure, $33.8 \%(45 / 133)$ in the operating room $(69 \%$ due to hygiene measures in the operating vs the office and $31 \%$ by request of the medical insurer) and $21.1 \%(28 / 133)$ in their medical office.

About the application of IVI in both eyes, 63.2\% (84/ 133) referred never inject both eyes on the same day, $24.8 \%$ (33/133) inject both eyes on the same day only under special circumstances and 12\% (16/133) inject always both eyes on the same day. Among the participants who referred to inject both eyes on the same day, $57 \%$ (28/ 49) referred to employ different vials and batches of medication for each eye and $43 \%(21 / 49)$ used the same vial for both eyes.

Pre-injection antibiotic drops were prescribed by $21.8 \%(29 / 133)$ of participants. Seventy-six percent (22/ 29) used quinolones and 20.7\% (6/29) aminoglycosides, of which $17.2 \%(5 / 29)$ reported using any of these antibiotics in combination with a steroid. Three percent $(1 / 29)$ did not specify the antibiotic they prescribed.

\section{Pre-Injection Procedures}

To obtain the dose of the drug to be injected into the vitreous cavity: $47.4 \%$ (63/133) used aliquots that were previously divided from a vial, $39.8 \%(53 / 133)$ used a vial from which they took multiple doses to use in different patients, $12.8 \%(17 / 133)$ took the dose from the vial and injected it, using only one vial per eye.

Forty-eight percent (46/96) cleaned the vial cap with povidone-iodine, $38.5 \%$ (37/96) with alcohol, while $13.5 \%$ (13/96) reported not cleaning the vial cap.

To inject the medication, $16 \%$ (16/100) utilized the same needle for drawing the medication from the vial and applying the IVI, while $84 \%(84 / 100)$ used a needle to draw the medication and a different one to perform the injection.

Regarding the use of a face mask, $96.2 \%$ (128/133) of the participants reported to wear a face mask during the procedure. Among them, 54\% (69/128) reported that the face mask was only worn by the physician, while in the remaining $46 \%$ $(59 / 128)$ the face mask was worn by both the physician and the patient. In 3\% (4/133) of cases, masks were not worn by neither the physician nor the patient and in $0.75 \%(1 / 133)$ the patient was the only one wearing the face mask. Eighty-six percent of participants asked the patient not to talk during the procedure, despite the use of a face mask.

Ninety-one percent (121/133) of participants referred the use of gloves for the IVI ( $97 \%$ [117/121] sterile gloves and 3\% [4/121] nonsterile gloves). A lid speculum was 
used during the IVI by $82.7 \%(110 / 133)$ of the participants. Regarding the position of the patient during the procedure, $48.9 \%(65 / 133)$ preferred a supine position, while $36.1 \%(48 / 133)$ used a semi-sitting position and $15 \%(20 / 133)$ a sitting position.

For anesthesia, 97\% (129/133) of participants used tetracaine drops, while $2.3 \% \quad(3 / 133)$ utilized subconjunctival lidocaine and only $0.8 \%$ (1/133) applied lidocaine as a gel. Considering all anesthetic options, 63.9\% $(85 / 133)$ referred to administrate the medication from 5 to 10 minutes before the procedure, 26.3\% (35/133) right before the injection and $9.8 \%(13 / 133)$ more than 15 minutes before.

All participants performed antisepsis using povidoneiodine before the IVI. Seventy-four percent (99/133) used the povidone-iodine at a concentration of 5\%, 13.5\% (18/ $133)$ at a concentration of $10 \%$ and $12 \%(16 / 133)$ at a concentration below 5\%. Regarding the area where the povidone-iodine was applied, 67\% (89/133) referred to apply it on periocular skin, eyelids and the conjunctival sac, $24 \%(32 / 133)$ only on eyelid margins and the conjunctival sac and $9 \%(12 / 133)$ only on the conjunctival sac.

\section{IVI Technique}

Eighty percent (107/133) measured the distance from the corneal limbus to the site of the injection. In order to obtain the measure, $84 \%(90 / 107)$ used a caliper and $15.9 \%(17 / 107)$ the needle cap. Regarding the quadrant to place the injection, $63.2 \%(84 / 133)$ preferred to perform it in the superotemporal quadrant, followed by $34.6 \%$ (46/ $133)$ in the inferotemporal and $2.3 \%(3 / 133)$ in the superonasal.

Concerning the gauge of the needle, $43.6 \%$ (58/133) of participants used $30 \mathrm{G}, 28.6 \%(38 / 133) 31 \mathrm{G}, 15 \%(20 /$ 133) $27 \mathrm{G}, 9.8 \%(13 / 133) 32 \mathrm{G}$ and $3 \%(4 / 133) 25$ G. After the injection, $80.5 \%$ (107/133) made pressure with a cotton swab to avoid vitreous leaking.

\section{Post-IVI Procedures}

Twenty-three percent of participants (30/133) did not prescribe antibiotic drops after the injection. Fifty-nine percent (79/133) recommended antibiotic drops for several days after the injection and 18\% (24/133) applied only one dose immediately after the injection. Among those who used post-injection antibiotics drops: 70.9\% (73/ 103) utilized quinolones, $17.5 \%$ (18/103) aminoglycosides and $19.4 \%(20 / 133)$ of them referred to use antibiotics combined with steroids.

Seventy-four percent (99/133) of participants did not utilize a hypotensive agent before or after the IVI, $18 \%$ (24/133) applied this medication only under special circumstances (ocular hypertension/glaucoma), while $7.5 \%$ $(10 / 133)$ reported to use it on every procedure.

Fifty-three percent (70/133) affirmed to check counting fingers visual acuity right after the injection. Only $2.3 \%$ (3/133) referred to perform a paracentesis on a regular basis after every procedure. Fifty-six percent (74-133) placed an eye-patch after the injection.

Regarding follow-up examinations after IVI, 38.3\% $(51 / 133)$ of participants performed an examination at their office $1-5$ days after the procedure, $36.8 \%(49 / 133)$ did not examine the patient until the appointment for the next IVI, $12.8 \%$ (17/133) performed an examination between days $7-15$ post-IVI and 12\% (16/133) did not perform an examination, but they did a follow-up phone call to the patient a few days after the IVI.

\section{Discussion}

This survey shows the diversity that exists in the different phases of the application of intravitreal injections among retina specialists in Mexico, and that in many aspects these practices differ from what has been previously reported in other countries.

Regarding the practice of applying bilateral injections on the same day, our study reported less bilateral injections compared to other countries such as the USA, where the frequency of this practice ranged between $45 \%$ and $71.5 \%{ }^{6,7}$ Other countries with a higher frequency were Canada (57\%), Israel (56\%), India (46\%) and Brazil $(36 \%)^{8-11}$ (Table 1).

Previous studies have reported that bilateral injections performed on the same day are well tolerated and can save time and money to the patients, without increasing the risk of endophthalmitis $^{12}$ or other systemic adverse events. ${ }^{13,14}$ The WHO, along with the Royal College of Ophthalmologists from the United Kingdom, suggest that the second injection should be considered as a totally new procedure, independent from the first one. This means that it requires the use of a new set of sterile gloves, a fresh preparation of povidone-iodine for antisepsis, a new and sterile caliper, lid speculum and surgical sheets in order to reduce the risk of infection or cross-contamination. ${ }^{15,16}$

Most of the participants referred to apply the IVI in a room specially dedicated for this procedure. Data from 
Table I Comparison of Intravitreal Injection Practice Patterns Between This Study and Previous Studies

\begin{tabular}{|c|c|c|c|c|c|c|c|c|}
\hline & $\begin{array}{l}\text { Canada } \\
2014 \\
\text { Xing } \\
\text { et } \text { al }^{8}\end{array}$ & $\begin{array}{l}\text { USA \& others } \\
2019 \\
\text { Uhr et } \mathrm{al}^{7}\end{array}$ & $\begin{array}{l}\text { USA } \\
2019 \\
\text { Chaturvedi } \\
\text { et al }{ }^{6}\end{array}$ & $\begin{array}{l}\text { Israel } \\
2016 \\
\text { Segal } \\
\text { et al }\end{array}$ & $\begin{array}{l}\text { India } \\
2020 \\
\text { Sundar } \\
\text { et al }\end{array}$ & $\begin{array}{l}\text { Brazil } \\
2015 \\
\text { Shiroma } \\
\text { et al }{ }^{11}\end{array}$ & $\begin{array}{l}\text { Europe } \\
2016 \\
\text { Huang } \\
\text { et } \mathrm{al}^{20}\end{array}$ & $\begin{array}{l}\text { Mexico } \\
2020 \\
\text { Henaine- } \\
\text { Berra et al } \\
\text { (current } \\
\text { study) }\end{array}$ \\
\hline $\begin{array}{l}\text { Number of } \\
\text { participants } \\
\text { (Survey response } \\
\text { rate) }\end{array}$ & 75 (64\%) & $399(14 \%)$ & $28 \mathrm{I}(17 \%)$ & 52 (66\%) & $74 \mid$ (73\%) & 352 (38\%) & $\begin{array}{l}113 \\
(90 \%)\end{array}$ & I 33 (78\%) \\
\hline
\end{tabular}

\section{Pre-IVI procedures}

\section{Setting}

\begin{tabular}{|c|c|c|c|c|c|c|c|c|}
\hline Physician's office & $72 \%$ & $72 \%$ & N/A & N/A & & $5 \%$ & $3.5 \%$ & $21 \%$ \\
\hline Procedure room & $N / A$ & $23 \%$ & & & $8 \%$ & $7 \%$ & & $45 \%$ \\
\hline Operating room & $28 \%$ & $5.5 \%$ & & & $91 \%$ & $88 \%$ & $68 \%$ & $34 \%$ \\
\hline $\begin{array}{l}\text { Simultaneous } \\
\text { bilateral } \\
\text { injections }\end{array}$ & $57 \%$ & $71.5 \%$ & $45 \%$ & $56 \%$ & N/A & $36 \%$ & N/A & $12 \%$ \\
\hline $\begin{array}{l}\text { Pre-IVI } \\
\text { antibiotics }\end{array}$ & $20 \%$ & $11 \%$ & $21 \%$ & $\mathrm{~N} / \mathrm{A}$ & $60 \%$ & $N / A$ & $67 \%$ & $22 \%$ \\
\hline Face mask & $29 \%$ & $33 \%$ & $36 \%$ & $37 \%$ & $98 \%$ & $\mathrm{~N} / \mathrm{A}$ & N/A & $97 \%$ \\
\hline Gloves & $39 \%$ & $55 \%$ & $73 \%$ & $79 \%$ & $98 \%$ & $95 \%$ & $75 \%$ & $91 \%$ \\
\hline Lid speculum & $91 \%$ & $72 \%$ & $66 \%$ & $98 \%$ & $96 \%$ & $95 \%$ & $81 \%$ & $83 \%$ \\
\hline Anesthesia & $\begin{array}{l}\text { Drops } \\
\text { combined } \\
\text { with other } \\
\text { methods: } \\
90 \% \\
\text { Drops } \\
\text { only: } 29 \% \\
\text { Gel: } 25 \% \\
\text { Swab: } 23 \% \\
\text { SC: } 23 \%\end{array}$ & $\begin{array}{l}\text { Drops:63\% } \\
\text { Gel: } 32 \% \\
\text { SC: } 27 \% \\
\text { Swab: } 19 \% \\
\text { Others: } 3 \%\end{array}$ & $\begin{array}{l}\text { Gel with or } \\
\text { without } \\
\text { drops: } 31 \% \\
\text { SC with or } \\
\text { without } \\
\text { drops: } 27 \% \\
\text { Drops only: } \\
16 \% \\
\text { Drops + } \\
\text { swab: } 14 \%\end{array}$ & $\begin{array}{l}\text { Drops } \\
\text { +gel: } \\
67 \% \\
\text { Drops } \\
\text { only: } \\
25 \% \\
\text { Gel only: } \\
8 \%\end{array}$ & $\begin{array}{l}\text { Local } \\
\text { anesthesia:91\% }\end{array}$ & $\begin{array}{l}\text { Drops only: } \\
67 \% \\
\text { Drops + gel: } \\
20 \%, \\
\text { Peribulbar: } 3 \%\end{array}$ & N/A & $\begin{array}{l}\text { Drops: } 97 \% \\
\text { SC: } 2 \% \\
\text { Gel: } 1 \%\end{array}$ \\
\hline Antisepsis & PI: $100 \%$ & $\begin{array}{l}\text { PI: } 97.5 \% \\
\text { Clorhexidine:2\% }\end{array}$ & PI: $100 \%$ & $\mathrm{~N} / \mathrm{A}$ & $\mathrm{N} / \mathrm{A}$ & Pl:99\% & $\mathrm{PI}: 90 \%$ & $\mathrm{PI}: 100 \%$ \\
\hline \multicolumn{9}{|c|}{ Injection technique } \\
\hline \multicolumn{9}{|l|}{ Quadrant } \\
\hline Superotemporal & $43 \%$ & $\begin{array}{l}\text { OD } 32 \% \\
\text { OS } 30 \%\end{array}$ & $27 \%$ & $33 \%$ & $\mathrm{~N} / \mathrm{A}$ & $\mathrm{N} / \mathrm{A}$ & $\mathrm{N} / \mathrm{A}$ & $63 \%$ \\
\hline Inferotemporal & $63 \%$ & $\begin{array}{l}\text { OD } 62 \% \\
\text { OS } 61 \%\end{array}$ & $70 \%$ & $17 \%$ & $\mathrm{~N} / \mathrm{A}$ & $\mathrm{N} / \mathrm{A}$ & N/A & $35 \%$ \\
\hline Superonasal & $7 \%$ & $\begin{array}{l}\text { OD } 1.5 \% \\
\text { OS } 4 \%\end{array}$ & $0 \%$ & $6 \%$ & N/A & $\mathrm{N} / \mathrm{A}$ & N/A & $2 \%$ \\
\hline
\end{tabular}

(Continued) 
Table I (Continued).

\begin{tabular}{|c|c|c|c|c|c|c|c|c|}
\hline & $\begin{array}{l}\text { Canada } \\
2014 \\
\text { Xing } \\
\text { et } \text { al }^{8}\end{array}$ & $\begin{array}{l}\text { USA \& others } \\
2019 \\
\text { Uhr et } \mathrm{al}^{7}\end{array}$ & $\begin{array}{l}\text { USA } \\
2019 \\
\text { Chaturvedi } \\
\text { et } \text { al }^{6}\end{array}$ & $\begin{array}{l}\text { Israel } \\
2016 \\
\text { Segal } \\
\text { et } \text { al }^{9}\end{array}$ & $\begin{array}{l}\text { India } \\
2020 \\
\text { Sundar } \\
\text { et al }^{10}\end{array}$ & $\begin{array}{l}\text { Brazil } \\
2015 \\
\text { Shiroma } \\
\text { et al }\end{array}$ & $\begin{array}{l}\text { Europe } \\
2016 \\
\text { Huang } \\
\text { et al }\end{array}$ & $\begin{array}{l}\text { Mexico } \\
2020 \\
\text { Henaine- } \\
\text { Berra et al } \\
\text { (current } \\
\text { study) }\end{array}$ \\
\hline Inferonasal & $7 \%$ & $\begin{array}{l}\text { OD } 5 \% \\
\text { OS } 5 \%\end{array}$ & $4 \%$ & $4 \%$ & $N / A$ & $\mathrm{~N} / \mathrm{A}$ & $N / A$ & $0 \%$ \\
\hline $\begin{array}{l}\text { Measurement } \\
\text { of distance } \\
\text { from corneal } \\
\text { limbus to site of } \\
\text { puncture }\end{array}$ & $56 \%$ & $30.5 \%$ & $20 \%$ & $69 \%$ & $\mathrm{~N} / \mathrm{A}$ & $80 \%$ & $\mathrm{~N} / \mathrm{A}$ & $80 \%$ \\
\hline \multicolumn{9}{|c|}{ Needle gauge for intraocular injection } \\
\hline $25 \mathrm{G}$ & N/A & N/A & NE & 0 & N/A & N/A & N/A & $3 \%$ \\
\hline $27 \mathrm{G}$ & N/A & $\mathrm{N} / \mathrm{A}$ & $1 \%$ & $4 \%$ & $N / A$ & $\mathrm{~N} / \mathrm{A}$ & $\mathrm{N} / \mathrm{A}$ & $15 \%$ \\
\hline $30 \mathrm{G}$ or more & N/A & N/A & $89 \%$ & $90 \%$ & N/A & $48 \%$ & N/A & $82 \%$ \\
\hline \multicolumn{9}{|c|}{ Method for preventing vitreous reflux } \\
\hline Swab & $41 \%$ & $\mathrm{~N} / \mathrm{A}$ & $37 \%$ & N/A & $N / A$ & $\mathrm{~N} / \mathrm{A}$ & $\mathrm{N} / \mathrm{A}$ & $80.5 \%$ \\
\hline $\begin{array}{l}\text { Angled scleral } \\
\text { tunnel technique }\end{array}$ & $7 \%$ & $\mathrm{~N} / \mathrm{A}$ & $\mathrm{N} / \mathrm{A}$ & $N / A$ & $N / A$ & $30 \%$ & $\mathrm{~N} / \mathrm{A}$ & $\mathrm{N} / \mathrm{A}$ \\
\hline $\begin{array}{l}\text { Conjunctival } \\
\text { displacement }\end{array}$ & $11 \%$ & $20.1 \%$ & $\mathrm{~N} / \mathrm{A}$ & $21 \%$ & $\mathrm{~N} / \mathrm{A}$ & $58 \%$ & $\mathrm{~N} / \mathrm{A}$ & $\mathrm{N} / \mathrm{A}$ \\
\hline None & $40 \%$ & $\mathrm{~N} / \mathrm{A}$ & $\mathrm{N} / \mathrm{A}$ & $N / A$ & $N / A$ & $\mathrm{~N} / \mathrm{A}$ & $\mathrm{N} / \mathrm{A}$ & $19.5 \%$ \\
\hline \multicolumn{9}{|c|}{ Post-IVI procedures } \\
\hline $\begin{array}{l}\text { Use of } \\
\text { antibiotics } \\
\text { post-IVI }\end{array}$ & $20 \%$ & $\begin{array}{l}\text { I7\% Always or } \\
\text { often instills } \\
\text { antibiotics } \\
\text { immediately } \\
\text { after injection, } \\
9 \% \\
\text { Always or often } \\
\text { prescribes } \\
\text { antibiotics for } \\
\text { home use }\end{array}$ & $28 \%$ & $92 \%$ & $\begin{array}{l}89 \% \text { for } \\
\text { several days }\end{array}$ & $\begin{array}{l}89 \% \text { for several } \\
\text { days }\end{array}$ & $89.5 \%$ & $\begin{array}{l}59 \% \text { for } \\
\text { several days, } \\
18 \% \text { one } \\
\text { drop } \\
\text { immediately } \\
\text { after } \\
\text { injection }\end{array}$ \\
\hline $\begin{array}{l}\text { AC } \\
\text { paracentesis } \\
\text { (pre or post } \\
\text { injection) }\end{array}$ & $51 \%$ & $\begin{array}{l}14 \% \text { in patients } \\
\text { with advanced } \\
\text { glaucoma }\end{array}$ & $\begin{array}{l}10 \% \\
\text { performed } \\
25 \% \text { of the } \\
\text { time }\end{array}$ & $\begin{array}{l}27 \% \text { in } \\
\text { cases of } \\
\text { end- } \\
\text { stage } \\
\text { glaucoma }\end{array}$ & $N / A$ & $\begin{array}{l}\text { Always } \\
\text { performed:11\% } \\
\text { Performed } \\
\text { when } \\
\text { necessary: } 54 \%\end{array}$ & $\mathrm{~N} / \mathrm{A}$ & $2 \%$ \\
\hline $\begin{array}{l}\text { Verify optic } \\
\text { nerve perfusion }\end{array}$ & $48 \%$ & $56 \%$ & $\begin{array}{l}4 \% \text { checked } \\
\text { for visual } \\
\text { acuity }\end{array}$ & $44 \%$ & $N / A$ & $25 \%$ & $N / A$ & $\begin{array}{l}53 \% \text { checked } \\
\text { counting } \\
\text { fingers visual } \\
\text { acuity }\end{array}$ \\
\hline
\end{tabular}

Abbreviations: N/A, not available; Pl, povidone-iodine; $\mathrm{AB}$, antibiotics; SC, sub-conjunctival, $\mathrm{AC}$, anterior chamber. 
other countries reveal relevant differences about the place for IVI application. In Canada, $72 \%$ used their office, on the other hand, in India, $91.4 \%$ performed the procedure in the operating room $^{13}$ (Table 1).

Previous publications have shown an incidence of endophthalmitis between $0.029 \%$ and $0.09 \%{ }^{10,13}$ when the IVI is performed at the physician office. These data suggest that this practice does not have an increased risk compared to the procedures performed in the operating room. A meta-analysis revealed that the incidence of endophthalmitis, when the IVI were performed in the operating room, was $0.07 \%$ compared to the $0.04 \%$ when the injection was applied at the physician's office. It is worth to mention that when the procedures were performed at the physician's office, the physicians did not use gloves, surgical sheets or face mask, but did use a lid speculum and povidone-iodine. ${ }^{17}$

All locations mentioned (operating room, procedure room or office) are safe and reliable to perform the IVI. ${ }^{18}$ The particular choice of setting could be related to different factors such as availability, cost and logistics within the different health systems.

\section{Use of Antibiotics}

Twenty-two percent of our participants confirmed the use of pre-IVI antibiotic drops. This percentage is higher compared to data from the USA, where only $10.9 \%$ of physicians prescribed them. However, in the United Kingdom and other European countries, the proportions were higher with $30 \%$ and $66.7 \%$, respectively. ${ }^{19,20}$

More than half of our participants (59.4\%) prescribed post-IVI antibiotics for several days, while in the USA they were prescribed only by $9.1 \%{ }^{2}$ and in the United Kingdom by $74 \%{ }^{19}$

Our study revealed that $18 \%$ prescribed only one dose of antibiotic drops immediately after the IVI. This percentage is similar to that observed in the USA $(16.6 \%){ }^{7}$ In the United Kingdom and Europe, this practice was carried out by $90 \%$ and $89.5 \%$, respectively. ${ }^{20}$

Surveys from Canada and Asia-Pacific showed that prophylactic antibiotic drops were applied by $43 \%$ and 84.9 of participants, respectively. ${ }^{8,21}$ Regarding post-IVI antibiotics, Brazil $(89.21 \%){ }^{11}$ India $(89.3 \%)^{10}$ and the United Kingdom $(74 \%)^{19}$ reported a higher frequency compared to ours.

Quinolones were the preferred antibiotics used by participants and the same behavior was observed in retina specialists from Canada. ${ }^{8}$ A previous study showed that in $87.5 \%$ of cases the conjunctival flora was resistant to quinolones after 4 days of treatment. ${ }^{22}$

Currently, there is sufficient evidence to support the fact that the use of topical antibiotics is not associated with a reduction in the incidence of endophthalmitis in the context of intravitreal injections, ${ }^{23-26}$ both post-injection ${ }^{27-29}$ and pre-injection, ${ }^{23,30}$ and it can contribute to microbial antibiotic resistance. ${ }^{22,31-34}$ The use of antibiotics before IVI plus the application of povidone-iodine does not confer an advantage over the use of povidone-iodine alone. ${ }^{23,24,30,35}$ Several studies and clinical practice guidelines affirm that the use of antibiotics before or after the IVI is unnecessary and reinforce that a proper antisepsis technique is the best prophylactic practice to avoid endophthalmitis. ${ }^{36-38}$ Furthermore, a higher risk of endophthalmitis was found in the group that used antibiotics in some studies, ${ }^{27,28,39,40}$ suggesting that repeated exposure to antibiotics may promote the development of resistant strains and this may lead to this paradoxical finding. ${ }^{2,22}$ Accumulated evidence suggests that the use of antibiotics before or after IVI does not reduce the risk of infection and it must not be used routinely. ${ }^{23,27,29}$

\section{Pre-IVI Procedures}

In our study, when off-label medications were used, several doses for different patients were taken from the same vial. When the medication was approved for intra-ocular application, the dose was directly taken from the vial and one vial was used for only one patient, or alternatively aliquots were previously prepared and stored under sterile conditions. Surveys carried out in other countries did not mention if the vial cap was cleaned before taking the dose.

There were no previous reports mentioning if physicians use one needle for taking the medication and a new needle for applying the IVI. General practice to avoiding infections suggests using a new, sterile needle for intravitreal medication delivery, different from the one used to draw the medication. ${ }^{41}$

Regarding the use of face mask, data obtained from surveys around the world have evidenced that the use of face mask is a very variable practice, ranging from $37 \%$ in Israel to $98 \%$ in India. 9,10

Several retrospective studies have demonstrated a positive correlation between the use of face mask plus the habit of not talking during IVI with a reduced risk of developing endophthalmitis, based on the reduction of potential contamination from the oropharyngeal flora. ${ }^{18,42-44}$ In a study published in 2011, in the setting of a simulated intravitreal injection, significantly greater 
bacterial dispersion was demonstrated when speaking without a mask than when speaking using a mask or remaining silent. ${ }^{45}$ It is worth to mention that this survey was carried out before the COVID-19 pandemic, so it is probable that the percentages of physicians and patients wearing a facemask has changed radically ever since.

There are no publications demonstrating that the use of gloves (sterile or nonsterile) correlated with a reduced risk of endophthalmitis. ${ }^{18}$ Nevertheless, some clinical practice guidelines recommend the use of gloves for the prevention of infections when working at the physician's office. ${ }^{1}$ Surveys from the USA, Canada and Brazil reported the use of gloves by $55 \%, 39 \%$ and $95 \%$ of physicians, respectively. ${ }^{7,8,11}$

In a survey from Israel, $79 \%$ of participants affirmed to use gloves (95\% of them used sterile gloves), ${ }^{9}$ whereas in India $98 \%$ of physicians used sterile gloves and a face mask during the procedure. ${ }^{10}$ On the other hand, $71 \%$ of the retina specialists in Israel utilized sterile surgical sheets and only $37 \%$ wore a face mask. ${ }^{9}$

Regarding the use of a lid speculum, surveys have shown a percentage of use of $98 \%, 96 \%$ and $66 \%$ in Israel, India and the USA, respectively. ${ }^{6,9,10}$ Recently, the use of the lid speculum has been replaced by manual retraction. Uhr and cols reported that the use of lid speculum dropped from $92 \%$ in 2011 to $72.3 \%$ in $2019 .^{7,46}$ In addition, Fineman and cols ${ }^{47}$ have demonstrated that assisted manual retraction is a safe technique. Their retrospective study found an incidence of endophthalmitis of $0.03 \%$, similar to the incidence associated to the use of lid speculum.

\section{Anesthesia}

The use of ophthalmic drops as anesthesia for the application of IVI was the preferred method in Canada (90\%) and Brazil $(67 \%) .{ }^{8,11}$

Regarding the application of sub-conjunctival anesthesia, this method provides a very effective analgesia for the application of IVI. However, the injection necessary to apply lidocaine in the subconjunctival space is usually more painful than other available methods or the procedure itself. Furthermore, a previous study showed that this injection provoked a sub-conjunctival hemorrhage in more than $50 \%$ of the cases. ${ }^{48}$ In some other surveys, ${ }^{7,8}$ subconjunctival anesthesia was mentioned as the preferred method for more than $20 \%$ of the participants.

The use of anesthesia as a gel is a less frequent practice among the retina specialists in our country. However, in
USA, Canada and Israel ${ }^{6-9}$ more than $25 \%$ of the participants referred the use of the gel as the election method, either alone or combined with ophthalmic drops. The use of gel anesthesia is controversial, since it has been reported that if the gel is applied before povidone-iodine, it may interfere with its antiseptic action and increase microbial survival. $^{49}$

Surveys from other countries do not mention the time elapsed between the application of the anesthesia and IVI. In our survey, $63.9 \%$ referred to apply the anesthesia 5-10 minutes before the procedure, $26.3 \%$ immediately before the injection and 9.8\% 15 minutes or more before the procedure. The anesthetic effect of proparacaine drops starts 20 seconds after its application and last for 10-15 minutes, whereas the effect of tetracaine drops starts 1 minute after its application and last for 15-20 minutes. ${ }^{50}$

\section{Antisepsis}

All of our participants referred to perform antisepsis with povidone-iodine before IVI. This behavior is similar in the USA, Canada and Brazil, where more than $99 \%$ of the physicians carry out antisepsis in the same way. $6,8,11$ Several publications have demonstrated that application of IVI without previous antisepsis importantly increases the risk of endophthalmitis. ${ }^{51-53}$

Most of the participants (74\%) used povidone-iodine at a concentration of $5 \%$. It has been demonstrated that povidone-iodine at a $5 \%$ concentration takes 2 minutes to eliminate $100 \%$ of the micro-organisms of the surface where it is applied. In addition, at this concentration, it causes less irritation of the ocular surface compared to $10 \%$ povidone-iodine. Furthermore, povidone-iodine at $10 \%$ takes 4 minutes to eliminate $100 \%$ of the microorganisms. $^{54}$ In conclusion, there is no advantage for using povidone-iodine at $10 \%$.

Regarding the area of application of povidone-iodine, a survey among retina specialists from Canada performed in 2014 revealed that $48 \%$ applied it on both the periocular skin and the conjunctival cul-de-sac. ${ }^{8}$

Other alternatives for antisepsis found in different surveys include the use of chlorhexidine and antibiotics either alone or in combination with povidone-iodine. ${ }^{7}$

\section{Injection Technique}

Both in our survey and those carried out in Israel $^{4}$ and Brazil, $^{11}$ more than $80 \%$ of participants referred to measure the exact distance from the corneal limbus to the site of injection using a caliper. On the other hand, retina 
specialists from the USA revealed that more than $60 \%$ of them did not measure the distance from the corneal limbus to the spot of injection. 6 ,

Regarding the quadrant where the injection is placed, surveys from Canada and the USA reported a preference for the inferotemporal quadrant in more than $60 \%$ of the participants $^{6-8}$ (Table 1).

About the gauge of the needle used for the puncture of the eye globe, most of the participants in our survey used a $30 \mathrm{G}$ needle. Our observation agrees with data obtained from surveys performed in Israel and the USA, where a $30 \mathrm{G}$ needle was used by $90 \%$ and $61 \%$, respectively. ${ }^{6,9}$

The use of a cotton swab as a method to prevent vitreous reflux through the site of puncture was a very common practice among our participants. Leaking is prevented by applying pressure with the cotton swab immediately after the puncture. Only two of the surveys (USA and Canada) $)^{6,8}$ reported its use, with around $40 \%$ of physicians practicing it, which contrasts with $80 \%$ in our survey.

\section{Post-IVI Procedures}

Only $7.5 \%$ of our participants used hypotensive drops routinely. This percentage is similar in Brazil, ${ }^{11}$ where it is used by $5 \%$ of retina specialists; in addition, $10 \%$ of Brazilian physicians prescribed oral acetazolamide. Eyes with no vitreous reflux at the time of injection have risk of suffering intraocular pressure elevation, which decreases without intervention in the following 30 minutes. Eyes with vitreous reflux present a reduction of the intraocular pressure which returns to normal in the following 10 minutes. ${ }^{55}$

In our survey, $52.6 \%$ corroborated immediate postinjection counting fingers vision, which, if present, is associated with adequate optic nerve perfusion. This practice is also performed in the USA $(21 \%-56 \%),{ }^{6,7}$ Canada $(48 \%)^{8}$ and Israel $(44 \%)^{9}$ (Table 1). In Canada and Israel, specialists referred to perform pupil dilation for an adequate examination after the injection.

Regarding anterior chamber paracentesis, in the Canadian $^{8}$ and Brazilian ${ }^{11}$ surveys, $5 \%$ and $11 \%$ of their respondents performed paracentesis in all their cases.

The routinely use of an eye-patch after the procedure was employed by $77.3 \%$ of the physicians in India. ${ }^{10}$ The use of an eye-patch is not recommended on the guides for the management of IVI published in 2014 in the USA. ${ }^{1}$ A study conducted in Hong Kong in $2015^{56}$ reported the use of eye-patch routinely with antibiotic ointment and the patch was removed when the patients arrived home.
The risk of adverse events related to IVI is relatively low. Therefore, there is no consensus regarding the examination after the procedure. In countries like India ${ }^{10}$ and Brazil $^{11}$, a follow-up examination at the office was performed within the first 2 weeks after injection by the $85 \%$ and $79 \%$, respectively.

\section{Conclusion}

Our study shows that there are different practices regarding the application of intravitreal injections among retina specialists in Mexico. The response rate of $78 \%$ was high, compared to surveys conducted in other countries. The limitation, as in any survey, was the bias in the selection of participants, in this case being answered only by active members of the Mexican Retina Association. Performing this type of survey periodically could show changes in preferences, as new evidence is incorporated into clinical practice.

\section{Abbreviations}

IVI, intravitreal injections.

\section{Data Sharing Statement}

The datasets used and/or analysed during the current study are available from the corresponding author on reasonable request.

\section{Consent for Publication}

Not applicable.

\section{Ethics Approval and Informed Consent}

Not applicable.

\section{Author Contributions}

All authors contributed to data analysis, drafting or revising the article, have agreed on the journal to which the article will be submitted, gave final approval of the version to be published, and agree to be accountable for all aspects of the work.

\section{Funding}

This study is partially funded by the Mexican Retina Association.

\section{Disclosure}

Gerardo Garcia-Aguirre reports personal fees from Alcon, Allergan, Bayer, Liomont, Novartis, Roche/Genentech, 
and Zeiss, outside the submitted work. The authors declare that they have no other potential conflicts of interest for this work.

\section{References}

1. Avery RL, Bakri SJ, Blumenkranz MS, et al. Intravitreal injection technique and monitoring: updated guidelines of an expert panel. Retina. 2014;34(Suppl 12):S1-S18. doi:10.1097/IAE.0000000 000000399

2. Aiello LP, Brucker AJ, Chang S, et al. Evolving guidelines for intravitreous injections. Retina. 2004;24(5 Suppl):S3-S19. doi:10.1097/00006982-200410001-00002

3. Grzybowski A, Told R, Sacu S, et al. 2018 update on intravitreal injections: euretina expert consensus recommendations. Ophthalmologica. 2018;239(4):181-193. doi:10.1159/000486145

4. Jonas JB, Spandau UH, Schlichtenbrede F. Short-term complications of intravitreal injections of triamcinolone and bevacizumab. Eye. 2008;22:590-591. doi:10.1038/eye.2008.10

5. Falavarjani KG, Nguyen QD. Adverse events and complications associated with intravitreal injection of anti-VEGF agents: a review of literature. Eye. 2013;27:787e 794.

6. Chaturvedi R, Wannamaker K, Riviere P, Khanani A, Wykoff C, Chao D. Real-world trends in intravitreal injection practices among american retina specialists. Ophthalmology Retina. 2019;3 (8):656-662. doi:10.1016/j.oret.2019.03.023

7. Uhr J, Xu D, Rahimy E, Hsu J. Current practice preferences and safety protocols for intravitreal injection of anti-vascular endothelial growth factor agents. Ophthalmology Retina. 2019;3(8):649-655. doi:10.1016/j.oret.2019.03.013

8. Xing L, Dorrepaal S, Gale J. Survey of intravitreal injection techniques and treatment protocols among retina specialists in Canada Canadian $J$ Ophthalmol. 2014;49(3):261-266. doi:10.1016/j. jcjo.2014.03.009

9. Segal O, Segal-Trivitz Y, Nemet AY, Geffen N, Nesher R, Mimouni M. Survey of intravitreal injection techniques among retina specialists in Israel. Clin Ophthalmol. 2016;14(10):1111-1116.

10. Sundar D, Das T, Chhablani J, Kumar A, Sharma N. All India Ophthalmological Society members' survey: practice pattern of intravitreal anti-vascular endothelial growth factor injection. Indian J Ophthalmol. 2020;68(6):1095-1098. doi:10.4103/ijo.IJO_1602_19

11. Shiroma H, Farah M, Takahashi W, Gomes A, Goldbaum M, Rodrigues E. Survey: technique of performing intravitreal injection among members of the brazilian retina and vitreous society (SBRV). Arq Bras Oftalmol. 2015;78(1):32-35.

12. Ruฟ£o M, Andreu-Fenoll M, Dolz-Marco R, Gallego-Pinazo R. Safety of bilateral same-day intravitreal injections of anti-vascular endothelial growth factor agents. Clin Ophthalmol. 2017;1 (11):299-302. doi:10.2147/OPTH.S124282

13. Davis RP, Schefler AC, Murray TG. Concomitant bilateral intravitreal anti-VEGF injections for the treatment of exudative age-related macular degeneration. Clin Ophthalmol. 2010;4:703-707.

14. Mahajan VB, Elkins KA, Russell SR, et al. Bilateral intravitreal injection of antivascular endothelial growth factor therapy. Retina. 2011;31(1):31-35. doi:10.1097/IAE.0b013e3181ed8c80

15. World Health Organization. Surgical safety checklist; 2016. Available from: http://www.who.int/patientssafety/safesurgery/checklist/en/. Accessed jul 7, 2020.

16. The Royal College of Ophthalmologists. Ophthalmic service guidance. Intravitreal injection therapy; 2018. Available from: https:// www.rcophth.ac.uk/wp-content/uploads/2018/02/IntravitrealInjection-Therapy-August-2018-2.pdf. Accessed July 7, 2020.

17. Tabandeh H, Boscia F, Sborgia A, et al. Endophthalmitis associated with intravitreal injections: office-based setting and operating room setting. Retina. 2014;34(1):18-23. doi:10.1097/IAE.0000000000000008
18. Storey PP, Patell D, Garg S. Endophthalmitis following intravitreal injection of anti-vascular endothelial grow factor agents. Can J Ophthalmol. 2020;55(4):286-292. doi:10.1016/j.jcjo.2020.01.015

19. Samia-Aly E, Cassels-Brown A, Morris DS, Stancliffe R, Somner JE. A survey of UK practice patterns in the delivery of intravitreal injections. Ophthalmic Physiol Opt. 2015;35(4):450-454. doi:10.1111/opo.12217

20. Huang K, Sultan MB, Zhou D, Tressler CS, Mo J. Practice patterns of ophthalmologists administering intravitreal injections in Europe: a longitudinal survey. Clin Ophthalmol. 2016;10:2485-2488. doi:10.2147/OPTH.S117801

21. Chhablani J, Shaikh A, Goud A, et al. Asia-pacific technology and trend survey 2016-2017. Asia Pac J Ophthalmol. 2019;8(1):43-54.

22. Milder E, Vander J, Shah C, Garg S. Changes in antibiotic resistance patterns of conjunctival flora due to repeated use of topical antibiotics after intravitreal injection. Ophthalmology. 2012;119(7):1420-1424. doi:10.1016/j.ophtha.2012.01.016

23. Moss JM, Sanislo SR, Ta CN. A prospective randomized evaluation of topical gatifloxacin on conjunctival flora in patients undergoing intravitreal injections. Ophthalmology. 2009;116(8):1498-1501. doi:10.1016/j.ophtha.2009.02.024

24. Bhavsar AR, Googe JM Jr, Stockdale CR, et al. Risk of endophthalmitis after intravitreal drug injection when topical antibiotics are not required: the diabetic retinopathy clinical research network laser-ranibizumab-triamcinolone clinical trials. Arch Ophthalmol. 2009;127(12):1581-1583. doi:10.1001/archophthalmol.2009.304

25. Benoist d'Azy C, Pereira B, Naughton G, Chiambaretta F, Dutheil F. Antibioprophylaxis in prevention of endophthalmitis in intravitreal injection: a systematic review and meta-analysis. PLoS One. 2016;11 (6):e0156431. doi:10.1371/journal.pone.0156431

26. Shrestha R, Karki P, Joshi SN. Outcome of intravitreal bevacizumab injection without pre and postoperative antibiotics. BMC Ophthalmol. 2020;20(1):145. doi:10.1186/s12886-020-01420-1

27. Storey P, Dollin M, Pitcher J, et al. The role of topical antibiotic prophylaxis to prevent endophthalmitis after intravitreal injection. Ophthalmology. 2014;121(1):283-289.

28. Cheung CS, Wong AW, Lui A, Kertes PJ, Devenyi RG, Lam WC. Incidence of endophthalmitis and use of antibiotic prophylaxis after intravitreal injections. Ophthalmology. 2012;119(8):1609-1614. doi:10.1016/j.ophtha.2012.02.014

29. Bhatt SS, Stepien KE, Joshi K. Prophylactic antibiotic use after intravitreal injection: effect on endophthalmitis rate. Retina. 2011;31(10):2032-2036. doi:10.1097/IAE.0b013e31820f4b4f

30. Park Y, Kim KS, Park YH. Acute endophthalmitis after intravitreal injection and preventive effect of preoperative topical antibiotics. J Ocul Pharmacol Ther. 2013;29(10):900-905. doi:10.1089/ jop.2013.0052

31. Kim SJ, Toma HS. Ophthalmic antibiotics and antimicrobial resistance a randomized, controlled study of patients undergoing intravitreal injections. Ophthalmology. 2011;118(7):1358-1363.

32. Kim SJ, Toma HS, Midha NK, Cherney EF, Recchia FM, Doherty TJ. Antibiotic resistance of conjunctiva and nasopharynx evaluation study: a prospective study of patients undergoing intravitreal injections. Ophthalmology. 2010;117(12):2372-2378. doi:10.1016/j. ophtha.2010.03.034

33. Yin VT, Weisbrod DJ, Eng KT, et al. Antibiotic resistance of ocular surface flora with repeated use of a topical antibiotic after intravitreal injection. JAMA Ophthalmol. 2013;131(4):456-461. doi:10.1001/ jamaophthalmol.2013.2379

34. Storey P, Dollin M, Rayess N, et al. The effect of prophylactic topical antibiotics on bacterial resistance patterns in endophthalmitis following intravitreal injection. Graefes Arch Clin Exp Ophthalmol. 2016;254(2):235-242. doi:10.1007/s00417-015-3035-x

35. Tanaka K, Shimada H, Mori R, Nakashizuka H, Hattori T, Okubo Y. No increase in incidence of post-intravitreal injection endophthalmitis without topical antibiotics: a prospective study. Jpn J Ophthalmol. 2019;63(5):396-401. doi:10.1007/s10384-019-00684-5 
36. Menchini F, Toneatto G, Miele A, Donati S, Lanzetta P, Virgili G. Antibiotic prophylaxis for preventing endophthalmitis after intravitreal injection: a systematic review. Eye. 2018;32(9):1423-1431. doi: 10.1038/s41433-018-0138-8

37. Lau PE, Jenkins KS, Layton CJ. Current evidence for the prevention of endophthalmitis in anti-vegf intravitreal injections. J Ophthalmol. 2018;2018:8567912.

38. Pachuo MA, Sahto AA, Quraishi, et al. Role of post-injection antibiotics after intravitreal bevacizumab injection in preventing endophthalmitis. Pak J Ophthalmol. 2015;31:44- 47.

39. Reibaldi M, Pulvirenti A, Avitabile T, et al. Pooled estimates of incidence of endophthalmitis after intravitreal injection of anti-vascular endothelial growth factor agents with and without topical antibiotic prophylaxis. Retina. 2018;38(1):1-11. doi:10.1097/ IAE.0000000000001583

40. Bande MF, Mansilla R, Pata MP, et al. Intravitreal injections of anti-VEGF agents and antibiotic prophylaxis for endophthalmitis: A systematic review and meta-analysis. Sci Rep. 2017;7(1):18088. doi:10.1038/s41598-017-18412-9

41. Sassalos TM, Paulus YM. Prefilled syringes for intravitreal drug delivery. Clin Ophthalmol. 2019;13:701-706. doi:10.2147/OPTH. S169044

42. McCannel CA. Meta-analysis of endophthalmitis after intravitreal injection of anti-vascular endothelial growth factor agents: causative organisms and possible prevention strategies. Retina. 2011;31 (4):654-661. doi:10.1097/IAE.0b013e31820a67e4

43. Doshi RR, Leng T, Fung AE. Reducing oral flora contamination of intravitreal injections with face mask or silence. Retina. 2012;32 (3):473-476.

44. Williams GA. IVT injections: health Policy Implications. Rev Ophthalmol. 2014;21:62-64.

45. Wen JC, McCannel CA, Mochon AB, Garner OB. Bacterial dispersal associated with speech in the setting of intravitreous injections. Arch Ophthalmol. 2011;129(12):1551-1554. doi:10.1001/archophthalmol. 2011.227

46. Green-Simms AE, Ekdawi NS, Bakri SJ. Survey of intravitreal injection techniques among retinal specialists in the United States. Am J Ophthalmol. 2011;151(2):329-332. doi:10.1016/j.ajo.2010.08.039
47. Fineman MS, Hsu J, Spirn MJ, Kaiser RS. Bimanual assisted eyelid retraction technique for intravitreal injections. Retina. 2013;33 (9):1968-1970. doi:10.1097/IAE.0b013e318287da92

48. Blaha GR, Tilton EP, Barouch FC, Marx JL. Randomized trial of anesthetic methods for intravitreal injections. Retina. 2011;31 (3):535-539. doi:10.1097/IAE.0b013e3181 eac724

49. Boden JH, Myers ML, Lee T, Bushley DM, Torres MF. Effect of lidocaine gel on povidone-iodine antisepsis and microbial survival. $J$ Cataract Refract Surg. 2008;34(10):1773-1775. doi:10.1016/j. jcrs.2008.05.056

50. Riordan-Eva P, Fraunfelder FW, McDaniel LM. Chapter 22: ophthalmic therapeutics. In: Riordan-Eva P, Augsburger JJ, editors. Vaughan \& Asbury $\neg ¥ s$ General Ophthalmology. 19th. Mc Graw Hill; 2018.

51. Peden MC, Hammer ME, $\mathrm{Su} \sqrt{ } \pm$ er IJ. Dilute povidone-iodine prophylaxis maintains safety while improving patient comfort after intravitreal injections. Retina. 2019;39(11):2219-2224. doi:10.1097/ IAE.0000000000002290

52. Modjtahedi BS, van Zyl T, Pandya HK, Leonard RE 2nd, Eliott D. Endophthalmitis after intravitreal injections in patients with self-reported iodine allergy. Am J Ophthalmol. 2016;170:68-74. doi:10.1016/j.ajo.2016.07.010

53. Bhavsar AR, Glassman AR, Stockdale CR, Jampol LM. Diabetic retinopathy clinical research network. elimination of topical antibiotics for intravitreous injections and the importance of using povidone-iodine: update from the diabetic retinopathy clinical research network. JAMA Ophthalmol. 2016;134(10):1181-1183. doi:10.1001/jamaophthalmol.2016.2741

54. Berkelman RL, Holland BW, Anderson RL. Increased bactericidal activity of dilute preparations of povidone-iodine solutions. $J$ Clin Microbiol. 1982;15(4):635-639. doi:10.1128/JCM.15.4.635639.1982

55. Morlet N, Young SH. Prevention of intraocular pressure rise following intravitreal injection. Br J Ophthalmol. 1993;77(9):572-573. doi:10.1136/bjo.77.9.572

56. Lai TY, Liu S, Das S, Lam DS. Intravitreal injection-technique and safety. Asia Pac J Ophthalmol. 2015;4(6):321-328. doi:10.1097/ APO.0000000000000146
Clinical Ophthalmology

\section{Publish your work in this journal}

Clinical Ophthalmology is an international, peer-reviewed journal covering all subspecialties within ophthalmology. Key topics include: Optometry; Visual science; Pharmacology and drug therapy in eye diseases; Basic Sciences; Primary and Secondary eye care; Patient Safety and Quality of Care Improvements. This journal is indexed on PubMed

\section{Dovepress}

Central and CAS, and is the official journal of The Society of Clinical Ophthalmology (SCO). The manuscript management system is completely online and includes a very quick and fair peer-review system, which is all easy to use. Visit http://www.dovepress.com/ testimonials.php to read real quotes from published authors. 